\title{
Knowledge level of shrimp farmers on better management practices (BMPs) of Penaeus vannamei farming: a comparative assessment of east and west coasts of India
}

\author{
M. KUMARAN, T. RAVISANKAR, P. R. ANAND, D. DEBORAL VIMALA \\ AND C. P. BALASUBRAMANIAN \\ ICAR-Central Institute of Brackishwater Aquaculture, 75, Santhome High Road, Chennai - 600 028, Tamil Nadu, India \\ e-mail:mkumaran@ciba.res.in
}

\begin{abstract}
Shrimp farmers need to have adequate knowledge and adopt better management practices (BMPs) for successful crop production. A study conducted among 240 proportionate random sample of shrimp farmers along the east and west coasts of the country has revealed that mean knowledge level of respondents was 52 and $44 \%$ respectively which needs improvement. Therefore, public-public and public-private partnership models integrating the efforts of research and development agencies, farmers groups and input companies need to be implemented for the capacity enhancement, increased access to quality inputs and services for the farmers. East coast has utilised $16 \%$ of its potential area and contributed $91 \%$ of country's shrimp production while west coast developed only $4 \%$ of potential area and contributed $9 \%$. Limited access to quality inputs and services constrained their production vis-a-vis potential in the west coast. It is suggested that a strategic aquaculture development plan for the west coast states of India involving aquaculture research and development agencies as well as input companies is the urgent need of the hour for developing hatcheries, diagnostic laboratories, recommending location specific production systems and better management practices to enhance the capacity of farmers and production in the west coast states.
\end{abstract}

Keywords: Better management practices, Knowledge level, Penaeus vannamei, Shrimp farmers

\section{Introduction}

Fisheries is one of the fastest growing food producing sectors and maintained a sustained growth of around 10\% in the last three decades. India's total fish production in 2014-15 was 10.07 million t comprising 6.58 million $\mathrm{t}$ of inland and 3.49 million $\mathrm{t}$ of marine fish production (DAHDF, 2016). India is one of the significant global seafood producers contributing $5.6 \%$ of world production and $2.5 \%$ of global trade. Indian seafood export revenue reached an all-time high of ₹37,871 crores (USD 5.78 million) in 2016-17 (MPEDA, 2017). Frozen shrimp continued to be the major item in the export basket in terms of quantity and value, accounting for a share of $38 \%$ in quantity and $65 \%$ in value worth USD 3,726.36 in the total export earnings. Farmed shrimps alone account for $51 \%$ of the total earnings and shrimp farming is being practiced in about 1.2 lakh ha with a production of 4.26 lakh t (MPEDA, 2016). The state-wise potential brackishwater aquaculture production and species farmed are presented in Table1. Shrimp is an important farmed aquatic crustacean species in the world and plays a great role in human nutritional needs due to its high protein, balanced amino acids profile, unsaturated fatty acids, vitamins and minerals (Salehi, 2010; Tazike, 2010).
Market demand for small-sized shrimp due to the global economic slump which followed the economic recession in the western countries during 2006-2008 and the specific pathogen free (SPF) status of Pacific white shrimp Penaeus vannamei paved way for the successful introduction of the species in South-east Asian countries and its subsequent introduction in India. Since introduction in 2009, it has been the candidate species of Indian shrimp farming. The culture of $P$. vannamei has been in a progressive pace and its production reached to the tune of 3,53,413 $\mathrm{t}$ in 2014-15. Presently $P$. vannamei is being farmed in diverse production systems with wide range of salinities, different levels of technology adoption ranging from extensive, zero water exchange to biofloc based intensive culture systems with varying densities, with and without farm level nurseries and earthen $v s$ lined ponds. Although SPF stocks are available, $P$. vannamei is also highly susceptible to pathogens in a non-biosecure environment. It has been observed that risk factors are present throughout the culture cycle from pond preparation to harvest and if they are not prevented/ managed properly, might lead to production losses and crop failure (Kumaran et al., 2016). Therefore it is important that the shrimp farmers have an adequate knowledge on the risk factors as well as better management practices (BMPs) in order to ensure successful crop. 
Table 1. Brackishwater aquaculture potential, shrimp farming area and production in the coastal states (MPEDA, 2016)

\begin{tabular}{|c|c|c|c|c|c|c|}
\hline State & $\begin{array}{l}\text { Potential area } \\
\text { in ha }(\mathrm{PA})\end{array}$ & $\begin{array}{l}\text { Area under } \\
\text { farming in } \\
\text { ha }(\mathrm{AF})\end{array}$ & $\begin{array}{l}\text { Potential utilised } \% \\
\mathrm{PA} / \mathrm{AF}\end{array}$ & $\begin{array}{l}\text { Production }(\mathrm{t}) \\
(\mathrm{P})\end{array}$ & $\begin{array}{l}\text { Production in } \% \text { to } \\
\text { India total }(\mathrm{P} / \mathrm{T})\end{array}$ & $\begin{array}{l}\text { Major species } \\
\text { cultured }\end{array}$ \\
\hline West Bengal & $4,05,000$ & 49374 & 12.19 & 53921 & 12.66 & P. monodon \\
\hline Odisha & 31,600 & 7732 & 24.47 & 21941 & 5.14 & P. vannamei and P. monodon \\
\hline Andhra Pradesh & $1,50,000$ & 39750 & 26.50 & 279039 & 65.50 & P. vannamei \\
\hline Tamil Nadu & 53,000 & 5075 & 9.58 & 32761 & 7.69 & P. vannamei \\
\hline East Coast & $6,39,600$ & 101931 & 15.94 & 387662 & 90.99 & \\
\hline Kerala & 65,000 & 13236 & 20.36 & 3655 & 0.86 & P. monodon \\
\hline Karnataka & 8,000 & 814 & 10.18 & 624 & 0.15 & P. vannamei and P.monodon \\
\hline Goa & 18,500 & 34 & 0.18 & 104 & 0.02 & P. vannamei and P.monodon \\
\hline Maharastra & 80,000 & 1401 & 1.75 & 5077 & 1.19 & P. vannamei \\
\hline Gujarat & $3,76,000$ & 4426 & 1.77 & 28920 & 6.79 & P. vannamei \\
\hline West coast & $5,47,500$ & 19911 & 3.64 & 38380 & 9.01 & \\
\hline Total (T) & $11,87,100$ & $1,21,842$ & 10.26 & $4,26,042$ & 100.00 & \\
\hline
\end{tabular}

World review of fisheries and aquaculture (2012) observed that when fish farmers do not have enough technical know-how to practice aquaculture as recommended for better production, they often employed traditional practices, which consequently resulted in poor yield. It is true that knowledge level of farmers could serve as a reasonably reliable predictor for adoption of better management practices. Knowledge about improved fish farming technologies is essential and aid in adoption of technologies (Saha, 2011; Sakib et al., 2014). The information on the extent of knowledge the farmers do have on the better management practices of $P$. vannamei farming is important for a well-targeted aquaculture planning and extension for a region. Similarly, to develop location specific farming systems, it is crucial to include farmers wisdom and location-specific knowledge of production constraints (Altieri, 2004; Altieri and Nicholls, 2004; Achigan-Dako et al., 2013). In this context, the present investigation was taken up to assess the knowledge level of shrimp farmers on BMPs of $P$. vannamei farming with a hypothesis that shrimp farmers significantly differ in their knowledge level across east and west coasts of India.

\section{Materials and methods}

The study was conducted in six coastal states of India viz., Andhra Pradesh, Tamil Nadu, Odisha, Karnataka, Goa and Maharashtra, three states each from the east and west coasts. A proportionate random sample of 240 shrimp farmers (131 from the east coast and 109 from the west coast) were approached and interviewed to collect primary data on the personal profile and knowledge level of shrimp farmers (Table 2). A set of twenty better management practices covering the entire shrimp production cycle which can reveal the knowledge level of farmers on $P$. vannamei farming were identified based on a brainstorming session with the subject matter specialists.
Table 2. State-wise sample size $(n=240)$

\begin{tabular}{llll}
\hline East coast & $\begin{array}{l}\text { Sample size } \\
(\mathrm{n} 1=131)\end{array}$ & West coast & $\begin{array}{l}\text { Sample size } \\
(\mathrm{n} 1=109)\end{array}$ \\
\hline Andhra Pradesh & 67 & Karnataka & 51 \\
Tamil Nadu & 40 & Goa & 17 \\
Odisha & 24 & Maharastra & 41 \\
\hline
\end{tabular}

An objective type teacher made knowledge test was developed to measure the knowledge of shrimp farmers. The knowledge items were validated for its content, language and coverage by the subject matter specialists. The correct response was given a score of one and wrong response was given a score of zero. Proper phrasing of items included in the knowledge test was done based on ascertaining the difficulty and discrimination indices of the items as suggested by earlier studies (Barman and Kumar, 2010; Kusuma Kumari and Sakeer Husain, 2016). Aknowledge index was calculated for each farmer as the ratio of individual respondent's score to the total possible score multiplied by 100 . The knowledge levels of the respondents were categorised into low, medium and high on the basis of mean and standard deviation as adopted by earlier studies (Sendilkumar, 2010; Sakib et al., 2014). A structured questionnaire was developed and pre-tested in a non-sampling area to collect primary data for the study from the respondents. Descriptive statistics and Mann-Whitney-U test of significance were employed to interpret the results and analyse the significant difference in the knowledge levels of the farmers.

\section{Results and discussion}

\section{Profile characteristics of shrimp farmers}

The socio-economic factors have significant influence towards diffusion and adoption of farming technologies 
(Lestrelin et al., 2012). Accordingly the general profile of the farmer respondents was studied and presented (Table 2). Around half of the respondents in the east $(50.37 \%)$ and west coast states $(44.03 \%)$ had matriculation to higher secondary level of education and about one fourth (29.77 and $26.60 \%$ respectivley) of them were graduates. This finding necessitates that technical information on shrimp farming needs to be given in vernacular language to the farming community. Aquaculture was the primary occupation and their livelihood was dependent on aquaculture for majority of respondents in both the regions (58.60 and $80.76 \%$ ). It implies that the farmers paid their maximum attention in shrimp farming and interested in receiving recent technical information on farming. Most of the east coast (94.65\%) and majority of the west coast respondents $(60.55 \%)$ had more than five years of farming experience. Similarly majority of the respondents had their own farms. Around one third of the respondents (36.64 and $34.86 \%$ ) had more than 5 ha of farm size and majority of them had less than 5 ha. Around one third of east coast farmers $(37.20 \%)$ and $17 \%$ of west coast farmers attended training on shrimp farming practices, however majority did not attend any structured institutional training. However, the respondents desired to have field level training on better management practices (BMPs) of shrimp farming during the month of January - February (pre-season training) for one to two days. Respondents reported that poor seed quality and diseases were the two major risk factors in shrimp farming in both the coasts (Table 3 ). Therefore, it is important that the farmers need to be trained in seed selection protocols and BMPs, as effective transfer of fish farming innovations to the farmers is the crucial link to improve the production (Singasand Manus, 2014).

The key production parameters of $P$. vannamei shrimp farming in the study area (Table 4) show that average farm holding was 6.5 and 4.8 ha respectively in east and west coasts. The farming experience was around 12 years. Seed stocking density reported in the east was $38 \mathrm{PL} \mathrm{m}^{-2}$ while in the west coast it was $26 \mathrm{PL} \mathrm{m}^{-2}$. Stocking density is the key factor that determines the level of farming operations and from the finding it may be noted that the east coast farmers were operating relatively at an intensive level than their west coast counterparts. The feed conversion ratio (FCR), size at harvest and duration of culture were almost similar in both the coasts. The average productivity reported in the west and east coasts were 4.5 and $6 \mathrm{t} \mathrm{ha}^{-1}$ respectively. This productivity difference may be due to the low stocking density practiced in the west coast. It was learnt that west coast farmers preferred to adopt lower densities mainly because of their inadequate access to quality inputs and services compared to the east coast farmers
Table 3. Profile characteristics of shrimp farmers

\begin{tabular}{|c|c|c|}
\hline \multirow{2}{*}{ Personal profile } & \multicolumn{2}{|c|}{$\%$ of farmers } \\
\hline & East coast $(n=131)$ & West coast $(n=109)$ \\
\hline \multicolumn{3}{|l|}{ Educational status } \\
\hline Primary school & 2.65 & 3.67 \\
\hline Middle school & 12.21 & 13.67 \\
\hline High school & 26.71 & 31.19 \\
\hline Higher secondary & 23.66 & 13.76 \\
\hline UG/Diploma & 29.77 & 26.60 \\
\hline PG and above & 4.58 & 11.01 \\
\hline \multicolumn{3}{|l|}{ Occupation } \\
\hline Aquaculture as primary & 58.60 & 80.76 \\
\hline $\begin{array}{l}\text { Aquaculture along with } \\
\text { others }\end{array}$ & 41.40 & 19.23 \\
\hline \multicolumn{3}{|l|}{ Farming experience } \\
\hline Less than 2 years & 2.29 & 14.67 \\
\hline 2 to 5 years & 3.05 & 24.78 \\
\hline More than 5 years & 94.65 & 60.55 \\
\hline \multicolumn{3}{|l|}{ Farm ownership } \\
\hline Owned & 83.42 & 65.10 \\
\hline Leased & 16.58 & 34.90 \\
\hline \multicolumn{3}{|l|}{ Farm size (ha) } \\
\hline Below 2 ha & 22.14 & 30.27 \\
\hline 2 to 5 ha & 41.22 & 26.60 \\
\hline Above 5 ha & 36.64 & 34.86 \\
\hline \multicolumn{3}{|c|}{ Training on shrimp farming } \\
\hline Attended & 37.20 & 17.10 \\
\hline Not attended & 62.80 & 82.90 \\
\hline \multicolumn{3}{|c|}{ Mode of technology transfer from Research Institutions } \\
\hline Mobile phone SMS & 39.69 & 62.38 \\
\hline Publications & 18.32 & 17.43 \\
\hline Online & 3.81 & 12.84 \\
\hline Interaction meetings & 49.61 & 12.84 \\
\hline $\begin{array}{l}\text { Constraints in } \\
\text { P. vannamei farming }\end{array}$ & $\begin{array}{l}\text { Disease, seed } \\
\text { quality, market rate } \\
\text { fluctuations }\end{array}$ & $\begin{array}{l}\text { Seed quality, } \\
\text { water quality, } \\
\text { disease problems, } \\
\text { lack of technical } \\
\text { help/assistance }\end{array}$ \\
\hline \multicolumn{3}{|l|}{ Training required } \\
\hline Subject matter & BMPs & BMPs \\
\hline Duration & 1-2 days & 1-2 days \\
\hline Preferred month & January - February & February \\
\hline
\end{tabular}

\section{Diffusion of technical information in shrimp aquaculture}

The pattern of spreading of technical information among shrimp farmers is depicted in Fig. 1. It may be noted that majority of the respondents in both the coasts $(62-63 \%)$ revealed that private input companies and their technicians were the major source of information 
Table 4. Production parameters of P. vannamei farming

\begin{tabular}{lll}
\hline Characteristics & $\begin{array}{l}\text { East Coast } \\
(\mathrm{n} 1=131)\end{array}$ & $\begin{array}{l}\text { West Coast } \\
(\mathrm{n} 2=109)\end{array}$ \\
\hline Farm size (ha) & $6.50 \pm 5.57$ & $4.84 \pm 5.07$ \\
Farming experience (years) & $12.53 \pm 6.14$ & $12.51 \pm 9.70$ \\
Stocking density (PL m $\left.{ }^{-2}\right)$ & $38.28 \pm 14.77$ & $26.02 \pm 11.21$ \\
Feed conversion ratio (FCR) & $1.42 \pm 0.16$ & $1.38 \pm 0.23$ \\
Shrimp size at harvest (g.) & $26.03 \pm 4.91$ & $26.59 \pm 7.05$ \\
Days of culture (days) & $119.70 \pm 17.98$ & $111.61 \pm 37.67$ \\
Productivity $\left(\mathrm{t} \mathrm{ha}^{-1}\right)$ & $6.08 \pm 1.09$ & $4.57 \pm 1.75$ \\
\hline
\end{tabular}

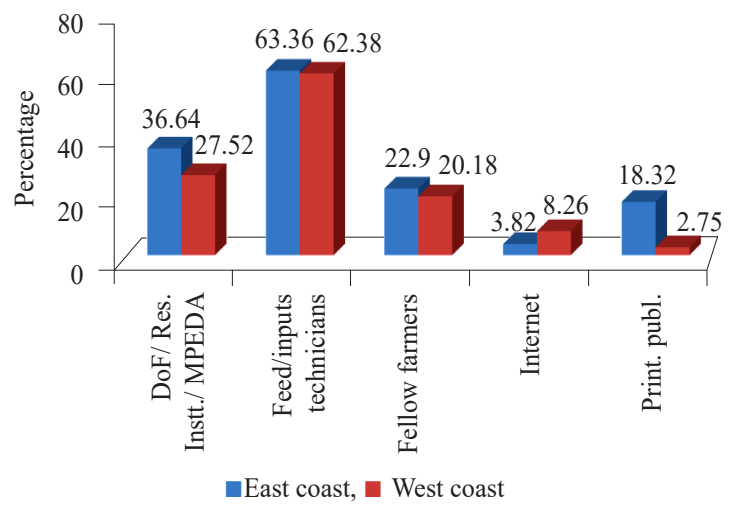

Fig 1. Diffusion of technical information in shrimp aquaculture

in all the technical aspects of farming. About one fourth of east $(27.52 \%)$ and one third $(36.64 \%)$ of west coast farmers approached institutional information sources viz., Research Institutes (RI), Marine Product Export Development Authority (MPEDA) and Department of Fisheries (DoF) for registration and technical guidance. About one fifth of the respondents in both the coasts reported that fellow progressive farmers (peers) were their source of information and triangulation of information obtained from other sources. Farmers were mostly dependent on private inputs particularly feed companies and independent consultants due to their easy accessibility, periodical visit to the farms, mobilising inputs/services and trust gained over a period of time. Institutional sources due to their limited manpower and pre-occupation with welfare, regulatory and administrative functions could not concentrate more on providing technical advisory services to the farmers. Earlier studies reported similar findings (Kumaran et al., 2004; 2012) on the information seeking behaviour of shrimp farmers.

\section{Knowledge level of farmers}

The knowledge level of shrimp farmers on BMPs of P. vannamei farming (Table 5, 6; Fig. 2) indicate that as a whole, the respondents did not have complete knowledge on the BMPs. Among the respondents, east coast farmers had relatively higher knowledge level (51.8\%) than
Table 5. Knowledge level of farmers on BMPs of $P$. vannamei farming

\begin{tabular}{lll}
\hline Knowledge level & $\begin{array}{l}\text { \% of East Coast } \\
\text { farmers (n1=131) }\end{array}$ & $\begin{array}{l}\text { \% of West Coast } \\
\text { farmers (n2=109) }\end{array}$ \\
\hline Low & 18.32 & 47.70 \\
Moderate & 66.41 & 33.94 \\
High & 15.26 & 18.34 \\
Mean knowledge level & $51.80 \%$ & $43.95 \%$ \\
Mann-Whitney test of & $5213.000^{* *}$ & \\
significance score & & \\
\hline
\end{tabular}

${ }^{* *}$ Significant at $1 \%$ level of probability $(\mathrm{p}<0.01)$

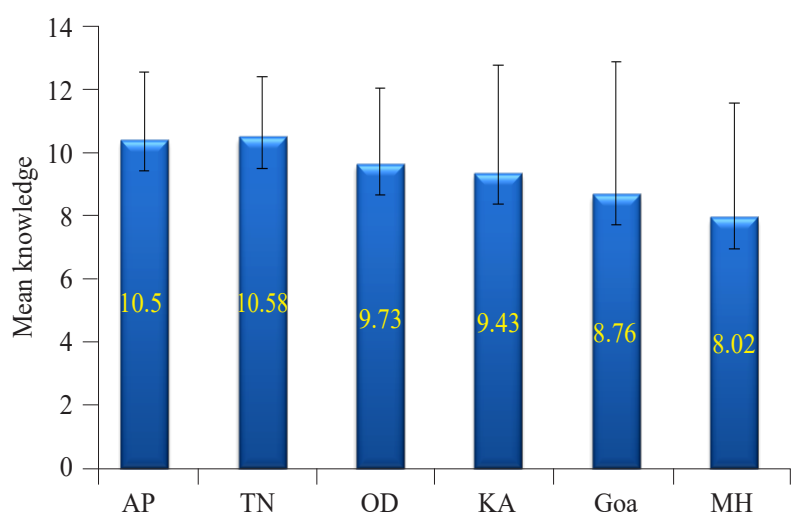

Fig. 2. State-wise mean knowledge score AP: Andhra Pradesh, TN: Tamil Nadu, OD: Odisha, KA: Kerala, MH: Maharashtra

their western counterparts $(43.95 \%)$. Moreover, around half $(47.7 \%)$ of the west coast respondents had lower knowledge levels. Guha (2006) and Saha (2011) reported knowledge score of 54 and $57 \%$ among the fish farmers on improved production practices of carp culture in Tripura and Bangladesh. Afruza Behum (2012) and Sakib et al. (2014) reported similar findings on the knowledge level of farmers on carp culture in Bangladesh. The non-parametric Mann-Whitney- $U$ test indicated that there is a significant difference in the knowledge levels of the farmers of east and west coasts and that the east coast farmers had a relatively better knowledge level than their west coast counterparts.

It may be noted that scientific shrimp farming was promoted initially in the east coast by the Indian Council of Agricultural Research (ICAR) and MPEDA in collaboration with respective State Fisheries Departments in the form of demonstrations, training of potential entrepreneurs and establishment of hatcheries for seed production which might have contributed for the better knowledge level of farmers in the east coast. However, efforts to promote shrimp farming in the west coast states were inadequate over these years. Low knowledge level of farmers in the west coast was 
akin to the practice of traditional and extensive mode of production systems followed in the west coast and their low production. Inadequate knowledge and partial adoption of BMPs might have caused poor productivity and disease related mortalities. Therefore, this knowledge and skill gap need to be narrowed down through adequate capacity building programmes at field level in the states to improve the knowledge levels, adoption of BMPs and increase in productivity. The practice-wise knowledge level of farmers is shown in Table 6 and may be noted that farmer respondents of both the coasts did not have adequate knowledge on critical practices like optimum size of post-larvae (PL) for stocking, total ammonia nitrogen (TAN) permissible in shrimp ponds, specific pathogen free (SPF) status of shrimp seed, temperature, $\mathrm{pH}$ and ammonia interaction, essential mineral requirements, osmo-ionic interaction in shrimp pond, early mortality disease, running mortality, carbon nitrogen $(\mathrm{C}: \mathrm{N})$ ratio in the shrimp pond water and nursery rearing.

The secondary data on brackishwater aquaculture (Table 1) pointed out that east coast states together have $54 \%$ of country's brackishwater aquaculture potential and the remaining $46 \%$ is in the west coast states. However, the area under shrimp farming in the east and west coasts respectively were 16 and $4 \%$ of their respective potential. Similarly the share of shrimp production from the east and west coast respectively were 91 and $9 \%$ (Fig. 3). It is a concern that development of aquaculture is very poor along the west coast. Most of the shrimp hatcheries and feed companies are located in the east coast and the west

Table 6. Knowledge level of farmers on BMPs of P. vannamei farming

\begin{tabular}{|c|c|c|}
\hline Practices & $\begin{array}{l}\% \text { of East Coast } \\
\text { farmers }(\mathrm{n} 1=131)^{*}\end{array}$ & $\begin{array}{l}\% \text { of West Coast } \\
\text { farmers }(\mathrm{n} 2=109)^{*}\end{array}$ \\
\hline No. of days of pond drying required between two successive cultures of $P$. vannamei is 21-35 days & 83.97 & 76.15 \\
\hline Normal carbon nitrogen ratio present in the shrimp pond water is approximately 10:1 & 22.14 & 8.26 \\
\hline $\begin{array}{l}\text { Farming of } P \text {. vannamei need deeper ponds than tiger shrimp because } P \text {. vannamei is a column } \\
\text { dweller and stocking density permitted is higher than tiger shrimp. }\end{array}$ & 61.07 & 44.95 \\
\hline Specific pathogen free (SPF) P. vannamei broodstock means broodstock is free of known pathogens. & 48.09 & 40.37 \\
\hline The optimum size of post-larvae for stocking is PL 12-14 & 45.04 & 33.03 \\
\hline The maximum stocking density permitted in P. vannamei farming by the CAA is 60 nos. $\mathrm{m}^{-2}$ & 84.73 & 29.36 \\
\hline Protein requirement in feed for $P$. vannamei is $30-35 \%$ & 52.67 & 44.95 \\
\hline $\begin{array}{l}\text { Feeding of } P \text {. vannamei should be avoided after } 1900 \text { hrs because it is a diurnal feeder and } \\
\text { DO problem is expected during night due to higher stocking. }\end{array}$ & 53.44 & 36.70 \\
\hline $\begin{array}{l}\text { Total ammonia nitrogen (TAN) is the sum total of both ionised }\left(\mathrm{NH}_{4}\right) \text { and unionised }\left(\mathrm{NH}_{3}\right) \\
\text { ammonia and level of TAN in } P \text {. vannamei ponds should be less than } 1 \mathrm{mg} \mathrm{l}^{-1}\end{array}$ & 37.40 & 38.53 \\
\hline Prolonged higher water temperature and $\mathrm{pH}$ will increase the ammonia level in pond water & 25.95 & 43.12 \\
\hline $\begin{array}{l}\text { P. vannamei shrimp requires essential minerals, Calcium, Magnesium and Potassium in the ratio } \\
\text { of } 1: 3: 1\end{array}$ & 41.22 & 35.78 \\
\hline $\begin{array}{l}\text { The optimal requirement of aerators for } P \text {. vannamei farming is } 1 \mathrm{HP} \text { for every } 350-400 \mathrm{~kg} \\
\text { of biomass }\end{array}$ & 58.78 & 53.21 \\
\hline $\begin{array}{l}\text { Provision of aeration in } P \text {. vannamei pond is important for enhancing the dissolved } \\
\text { oxygen and to keep the pond water in circulation }\end{array}$ & 64.12 & 58.72 \\
\hline $\begin{array}{l}\text { Mineral supplementation in } P \text {. vannamei pond is required for low saline culture to maintain the } \\
\text { Osmo-ionic equilibrium. }\end{array}$ & 40.46 & 23.85 \\
\hline $\begin{array}{l}\text { Osmo-ionic equilibrium in } P \text {. vannamei ponds means the ionic composition of the animal and } \\
\text { the rearing water should be almost equal. Otherwise the minerals move from the higher } \\
\text { concentration to lower concentration. }\end{array}$ & 34.35 & 34.86 \\
\hline Higher diurnal variation of $\mathrm{DO}$ and $\mathrm{pH}$ indicates that algal bloom is high. & 61.83 & 55.05 \\
\hline $\begin{array}{l}\text { Early mortality Syndrome (EMS) is major disease in other countries, the main organ affected } \\
\text { by EMS is hepatopancreas }\end{array}$ & 43.51 & 34.86 \\
\hline $\begin{array}{l}\text { Running mortality in } P \text {. vannamei is a problem due to poor pond preparation, poor quality seed, } \\
\text { poor pond management and high temperature, not due to pathogen }\end{array}$ & 48.85 & 66.97 \\
\hline $\begin{array}{l}\text { Nursery rearing by stocking PL } 10 \text { P. vannamei for one month period with a stocking density of } \\
500 \mathrm{PL} \mathrm{m} \mathrm{m}^{-2} \text { enhances the survival and better growth. }\end{array}$ & 50.38 & 41.28 \\
\hline $\begin{array}{l}\text { Partial harvesting of } 20 \% \text { of shrimp biomass at } 80-90 \text { DOC helps in minimising risks and aid in } \\
\text { better growth. }\end{array}$ & 78.63 & 79.82 \\
\hline
\end{tabular}

"Multiple responses 


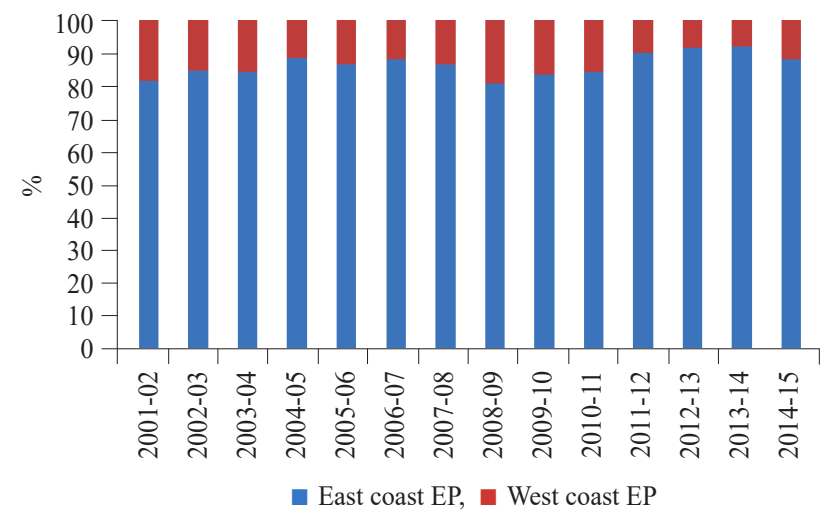

Fig. 3. Trends in Estimated Production(EP) of shrimp in India

coast farmers had limited access to the quality inputs and they need to pay $20 \%$ more to get the inputs. It was observed that inadequate knowledge on seed selection, transportation and dependence on the seed contractors (middlemen) to supply shrimp seed, affected shrimp farming along the west coast. Hence, it is important that the state fisheries departments of the west coast states need to ensure supply of quality shrimp seeds to their farmers through a contractual arrangement with registered hatchery operators in the east coast. Farmers need to be mobilised to form groups and source quality seeds through contracting registered hatcheries as practiced by some farmer groups in the east coast (Kumaran, 2009). Similarly, research institutions need to develop suitable farming systems and system specific BMPs to the west coast states considering their geographic conditions like tidal amplitude, seawater quality and climatic extremities.

The study has indicated that shrimp farmers need to enhance their capacities on BMPs of $P$. vannamei farming. The west coast farmers were in a disadvantageous position due to their limited access to institutions, quality inputs and knowledge sources, apart from the constraining agro-climatic conditions attributed to west coast of India. The knowledge gap on BMPs and limited access to quality inputs need to be sorted out to make the west coast improve its production proportionate to their potential. Considering the ground realities, promotional agencies need to implement a "strategic aquaculture plan for the west coast" and establish suitable model hatcheries, diagnostic laboratories, suggest area specific production systems and BMPs. The state fisheries departments and farmer associations should involve central and state research institutions to implement location specific on-field trainings on BMPs of shrimp farming for the field level extension workers and farmers to enhance the knowledge level and skill sets of farmers.

\section{Acknowledgements}

The authors gratefully acknowledge the National Fisheries Development Board (NFDB) for the financial support to take up this study. The authors are also grateful to the farmer respondents for sparing their time and responses. The authors gratefully acknowledge the support and encouragement provided by the Director, ICAR-CIBA, Chennai for conducting this study.

\section{References}

Achigan-Dako, E. G., Sogbohossou, O. D., Segnon, A. C., N'Danikou, S., Sinsin, A. B. and Vodouhe, S. R. 2013. Agricultural ecological intensification options in the West African sahel and dry savannas: Current knowledge and possible scenario; Bioversity International, West and Central Office, Cotonou, Benin, 84 pp.

Afruza Begum 2012. Aquaculture knowledge of small scale fish farmers in Sadar Upazila under Mymensingh District, M. Sc Thesis, Department of Aquaculture, Bangladesh Agricultural University, Mymensingh, Bangladesh, 41 pp.

Altieri, M. A. 2004. Linking ecologists and traditional farmers in the search for sustainable agriculture, Front. Ecol. Environ., 2: $35-42$.

Altieri, M. A. and Nicholls, C. I. 2004. An agro-ecological basis for designing diversified cropping systems in the tropics. J. Crop Improv., 11: 81-103.

Barman. U. and Kumar, B. 2010. A test to measure knowledge of extension personnel on farmers' group dynamics, Indian Res. J. Ext. Edn., 10(3): 119-123.

DAHDF 2016. Fisheries profile of India. Department of Animal Husbandry, Dairying and Fisheries, Ministry of Agriculture and Farmers Welfare, Govt. of India, http://dahd.nic.in/ sites/default/files/India\%20Profile\%20updated_0.pdf

Guha, A. 2006. Retention of fisheries knowledge by fish farmers of MAEP in some selected area of Gazipur District, M. Sc. Thesis, Department of Fisheries Management, Bangladesh Agricultural University, Mymensingh, Bangladesh, p. 25 - 30.

Kumaran, M. 2009. Sustainable aquaculture group approach to shrimp farming: the key to sustainability. Aquaculture Asia, XIV (3): 18-21.

Kumaran, M, Deboral Vimala, D., Chandrasekaran,V. S., Alagappan, M. and Raja, S. 2012. Extension approach for an effective fisheries and aquaculture extension service in India. J. Agric. Edn. Ext., 18(3): 247-267.

Kumaran. M., Ponnusamy, K. and Krishnan, M. 2004. Utilisation of information sources by shrimp farmers. Ind. J. Extn. Edn., XL(1\&2): 63-66 .

Kumaran, M., Ravichandran, P., Muralidhar, M., Ambasankar, K., Otta, S. K., Panigrahi, A., Deboral Vimala, D., Ravisankar, T., Asok Kumar, J., Anand, P. R., Johnson Paul and Vijayan, K. K. 2016. Frequently asked questions (FAQs) pertaining to Penaeus vannamei shrimp farming, ICAR-Central Institute 
of Brackishwater Aquaculture, Chennai, ISBN No. 978-81932937-1-3, 38 pp.

Kusuma Kumari, N. and Sakeer Husain, A. 2016. A standardised knowledge test to measure the extent of knowledge of agricultural extension personnel on m-tools. J. Ext. Edn., 28(1): 5614-561.

Lestrelin Guillaume, Nanthavong Khanla, Jobard Etienne, Keophoxay Anousith, Lienhard Pascal, Khambansenang, Chanxay Castella and Jean Christophe 2012. To till or not to till? The diffusion of conservation agriculture in Xieng Khouong Province, Lao PDR-Opportunities and constraints. Outlook on Agriculture, 41(1): 41-49.

MPEDA 2016. Species-wise fish production, Marine Products Development Authority. www.mpeda.org.in.

MPEDA.2017. India's seafood export at all-time high in 2016-17. Marine Products Export Development Authority. www.mpeda.org.in.

Saha, B. 2011. Knowledge level of the fish farmers in Tripura regarding scientific fish production practices. Journal of
Community Mobilisation and Sustainable Development, 6(1): 082-088.

Sakib, Md. H., Afrad. Md. S. I. and Foyez, A. Prodhan 2014. Farmers' knowledge on aquaculture practices in Bogra District of Bangladesh. Int. J. Agr. Ext., 2(02): 121-127.

Salehi, H. 2010. Investigation in Nutritionists tendency of the shrimp consumed in Iran. Iranian J. Natural Res., 63(4): 301-313.

Sendilkumar, R. 2010. Knowledge and information sources utilisation pattern of soybean growers. Indian Res. J. Ext. Edn., 10(3): 71-74.

Singas, S. and Manus, P. 2014. Factors influencing adoption of pond fish farming innovations in Potsy of Morobe Province, Papua New Guinea. Universal J. Agric. Res., 2(6): 191-197.

Tazike, A. 2010. Management of shrimp cultivation in farms. Noruzi Publication, $162 \mathrm{pp}$.

World Review of Fisheries and Aquaculture 2012. The state of world fisheries and aquaculture, $148 \mathrm{pp}$

Date of Receipt : : 07.01.2017

Date of Acceptance $\quad$ : 10.07 .2017 